\title{
Poultry Litter Biochar: An Approach towards Poultry Litter Management - A Review
}

\author{
Amita Shakya and Tripti Agarwal* \\ Department of Agriculture and Environmental Science, National Institute of Food Technology \\ Entrepreneurship and Management, Kundli, Sonepat 131 028, Haryana, India \\ *Corresponding author
}

\section{A B S T R A C T}

\begin{tabular}{|c|}
\hline Keywords \\
\hline $\begin{array}{l}\text { Poultry litter, } \\
\text { Biochar, Waste } \\
\text { management, Soil } \\
\text { amendment. }\end{array}$ \\
\hline Article Info \\
\hline $\begin{array}{l}\text { Accepted: } \\
23 \text { September } 2017 \\
\text { Available Online: } \\
10 \text { October } 2017\end{array}$ \\
\hline
\end{tabular}

Poultry litter is an abundantly available waste biomass, which is used for direct land applications since a long time. Direct use of poultry litter on agricultural lands causes many environmental concerns like, nutrient runoff, eutrophication, flaw odor, greenhouse gas emission due to decaying and microbial contamination. To reduce the environmental concerns, thermochemical conversion of poultry litter into biochar can be an economically sustainable approach. Poultry litter converted into biochar with pyrolysis process also produces additional value products, syngas and bio-oil. Use of poultry litter biochar can improve the soil fertility, water holding capacity and nutrient retention power. Poultry litter biochar also has capacity for remediation of organic and inorganic contaminants from soil and water.

\section{Introduction}

Biochar is a solid material obtained from the carbonization of biomass and may be added to soils with the intention to improve soil functions and to reduce greenhouse gas (GHG) emissions from the decomposition of biomass. Biochar is produced from intentionally heating a biomass feedstock via pyrolysis or gasification, typically in an oxygen limited environment, with the goal of creating a stable, carbon- rich product resistant to degradation in soils (IBI, 2012).

The characteristics of biochar, depends on how it is produced, and the raw material that is used (Kloss et al., 2012). Various residual and waste products can be converted into biochar including forestry, crop waste, food industry residual biomass and animal manures(Aditya Parmar, 2014). Temperature, residence time, rate of temperature increase, pre- and post- processing of feedstock and biochar, are the specific production parameters which affect the quality of the biochar, and can impact the nutrient availability to crops, the physical and chemical properties of the biochar, and the amount of stable carbon sequestered (Sun et al., 2014). The choice of raw material significantly impacts the end product and its uses. More than $50 \%$ of the organic matter's carbon may be restored in a stable form as biochar, but it highly depends on the 
production parameters. When the biochar is used as a soil amendment, a significant proportion of the recalcitrant biochar carbon can resist degradation for hundreds to even thousands of years, thus creating stable carbon pools (IBI, 2012). Biochar generally increases nutrient availability, soil organic matter, water retention, microbial activity and crop yield in soil while it decreases greenhouse gas emissions, need of fertilizers, nutrient leaching and erosion (Mohan et al., 2014). In addition, during the production process of biochar bio-oil and process heat is created which have many alternative uses.

The waste generated in agriculture, food industries and forestry either processed or unprocessed are the main sources of feedstock for biochar production. Wood chips and pellets, tree cuttings, bagasse, distiller grains, press cakes from oil and juice industry, rice husk and crop residues are the main(Aditya Parmar, 2014). At present many other potential biomass sources other than lignocellulosic matter such as sewage sludge, dairy manure, poultry litter, human and animal waste such as excrements, bones, feathers are extensively studied and recognized as potential raw material for low cost adsorbent preparation.

Poultry litter is one of the most potential and ample available biomass which can be exploited as raw material for biochar production. Direct use of poultry litter with or as compost in soil is a long time practice but several studies (Crippen et al., 2016; Uchimiya et al., 2010a), shows the concerns of mineral runoff and other environmental threats associated with direct use of poultry litter. Environmental contamination may happen when poultry wastes are applied in excess for crop utilization potential in land, or is done under poor management conditions which causes nutrient loss from environmental factors such as soil erosion or surface runoff during rainfall, and other parameters of concern are $\mathrm{N}, \mathrm{P}$, and certain metals $(\mathrm{Cu}$ and $\mathrm{Zn}$ in particular), as well as pathogenic microorganisms that may be contained in poultry waste (Williams et al., 1999). Thermochemical conversion of poultry litter into biochar (a more stable form) can be an approach to lower the burden of environmental contamination associated with poultry litter.

\section{Poultry litter}

Poultry Litter is a mixture of poultry excreta, feathers, spilled feed and material used as bedding to absorb liquid fractions of excreta, which typically include wood chips, sawdust, wheat straw, peanut hulls, and rice hulls, in poultry operations at large scales. Poultry litter includes litter from meat chickens (broilers), egg laying chickens (layers) which are kept under barn conditions, turkeys, ducks and quails. According to a published report nearly 6.25 million tonnes of poultry manure is produced in India annually (Prabhu, 2009) (Table 2).

\section{Composition of poultry litter}

According to analysis conducted by Weiping Song (2012), poultery litter contains magnesium $(\mathrm{Mg})$, calcium $(\mathrm{Ca})$, sulpher $(\mathrm{S})$, nitrogen $(\mathrm{N})$, phosphorus $(\mathrm{P})$, iron $(\mathrm{Fe})$, manganese $(\mathrm{Mn})$, potassium $(\mathrm{K})$ (Song and Guo, 2012). All these are the elements which are necessary for plant growth. Thought the nutrient content may vary considerably depending upon the conditions such as feed, bedding material, handling conditions etc.

\section{Poultry litter management}

In India, poultry production has been rising at the rate of 8 percent per annum, with an annual turnover of US\$ 7500 million (Rajesh Mehta). This massive poultry farming produces tons of wastage in terms of litter/ manure which has been used for composting, 
pelletizing, and converting to electricity, steam and biogas over the years. The most common use of the poultry litter is land application (Dunkley, 2011). It is also used as fish feed and livestock feed (M. Mohamed Amanullah, 2010). Poultry litter has been used as either the sole fertilizer or in combination with traditional inorganic fertilizers. Due to the concerns over N and P losses to surface waters after the land application of poultry litter, there's a need for regulation of poultry operations.

\section{Challenges in poultry litter management}

Despite of having several ways for using poultry litter, still it has some limiting factors which include handing, loss of nutrients, GHG emission during land application and long term storage, surface water contamination, emission of ammonia, nitrate emission, runoff of dissolved phosphate, immobilization, nutrient loss during long term storage due to volatilization and microbial contamination. Since poultry litter contain manure also, which has high moisture content due to which it cannot be applied to crops directly due to caustic effect on foliage (M. Mohamed Amanullah, 2010). Kithome et al., (1999), also reported that storage and direct land application of untreated poultry litter has many disadvantages like, odors, fly breeding and pathogen growth (Kithome, 1999). There is an immediate need for the additional strategies to effectively deal with this waste product. Converting the waste biomass into biochar can be a way better solution and it will help in carbon sequestration too. Poultry litter biochar offers a number of unique benefits in terms of field applications as well as in environmental pollution remediation.

\section{Poultry litter biochar}

Poultry Litter (PL) biochar is made from chicken manure and the bedding used in poultry operations like wood shavings, saw dust, straw or other organic materials - as well as feathers, feed spillage and mortalities (IBI, 2012).

\section{Poultry litter biochar production techniques}

Poultry litter biochar can be produced by thermal conversion techniques, which include slow pyrolysis, fast pyrolysis, hydrothermal carbonization, torrefication and gasification. Pyrolysis of the animal manure waste is the most frequently used technique to obtain the higher char yield. Pyrolysis process is highly dependent on heating rate, pressure, residence time, peak temperature, heat transfer rate, vapor-solid interactions (Judy A Libra, 2011).

Pyrolysis is the thermochemical decomposition of biomass in the oxygen free environment and is complex process, which can be categorized in three main stages (Demirbas, 2004)

Dehydration: Biomass $=$ water + dry organic mass

Initial charring: Dry organic mass $=$ tarry vapors + primary char

Final Charring: Primary char $=$ tarry vapors + secondary char

The tarry vapor is a mixture of heavier hydrocarbons, water vapors and noncondensable gases including $\mathrm{CO}_{2}, \mathrm{CO}, \mathrm{H}_{2}$, $\mathrm{CH}_{4}, \mathrm{C}_{2} \mathrm{H}_{2}$ and $\mathrm{C}_{3} \mathrm{H}_{6}$ (Mingxin Guo, 2012).

Pyrolysis process is of two types slow and fast and can be performed into muffle furnace, bed reactors, kiln furnace, tube furnace with $\mathrm{N}_{2}$ flow to create oxygen free environment. Fast pyrolysis is characterized by high heating rates and short vapor residence times, and a moderate (in pyrolysis terms) temperature of around $500^{\circ} \mathrm{C}$ is usually used (Brownsort, 2009). 
Table.1 Thermochemical process, resident time and primary product (Mohan et al., 2014)

\begin{tabular}{|l|l|l|l|l|l|}
\hline $\begin{array}{l}\text { Thermochemical } \\
\text { process }\end{array}$ & $\begin{array}{l}\text { Temp. } \\
\text { range }\end{array}$ & Heating Rate & Pressure & $\begin{array}{l}\text { Residence } \\
\text { Time }\end{array}$ & $\begin{array}{l}\text { Desired } \\
\text { Product }\end{array}$ \\
\hline Slow Pyrolysis & $350-800$ & Slow $\left(<10^{\circ} \mathrm{C} / \mathrm{min}\right)$ & Atmospheric & $\begin{array}{l}\text { Hours- } \\
\text { seconds }\end{array}$ & Biochar \\
\hline Torrefaction & $200-300$ & Slow $\left(<10^{\circ} \mathrm{C} / \mathrm{min}\right)$ & Atmospheric & $\begin{array}{l}\text { Minutes- } \\
\text { hours- }\end{array}$ & $\begin{array}{l}\text { Stabilized } \\
\text { Friable } \\
\text { biomass }\end{array}$ \\
\hline Fast pyrolysis & $400-600$ & $\begin{array}{l}\text { Very fast } \\
\left(\sim 1000^{\circ} \mathrm{C} / \mathrm{s}\right)\end{array}$ & $\begin{array}{l}\text { Vacuum- } \\
\text { atmospheric }\end{array}$ & seconds & Biooil \\
\hline Gasification & $700-1500$ & $\begin{array}{l}\text { Moderate to very } \\
\text { fast }\end{array}$ & $\begin{array}{l}\text { Atmospheric- } \\
\text { elevated }\end{array}$ & $\begin{array}{l}\text { Seconds- } \\
\text { minutes }\end{array}$ & Syngas \\
\hline $\begin{array}{l}\text { Hydrothermal } \\
\text { carbonization }\end{array}$ & $175-250$ & slow & - & Hours & Hydrochar \\
\hline
\end{tabular}

Slow pyrolysis is characterized by slower heating rates, long solid and vapor residence times and usually a lower temperature than fast pyrolysis, typically $400^{\circ} \mathrm{C}$. Char is the target product often, but always there will be liquid and gas product formation occur, although these are not always recovered (Brownsort, 2009).

\section{Characteristics of poultry litter biochar}

Soil with high cation exchange capacity will be able to retain cationic nutrient in the root zone and prevent the nutrient from deep leaching and it is evidenced that soil amendment with PL biochar have improved soil nutrient retention (Mingxin Guo, 2012). Cely et al., (2015) studied different kind of manure derived biochars and reported that chicken manure pyrolyzed at $300^{\circ} \mathrm{C}$ having the high cation exchange capacity and elevated stability, and potentially this type of biochar can be used in nutrient poor soils to increase the crop yields (Celya, 2015).

Similar results were also reported by Gaskin et al., (2008), which showed a significantly higher CEC in low temperature $\left(400^{\circ} \mathrm{C}\right)$ poultry litter biochar than in peanut hull and pine chip biochars at the same temperature (Gaskin, 2008).
A study by Das et.al, (2008) highlighted PL biochar with an ash content of $26 \%$ versus ash content of approx $2 \%$ from pine chip derived biochar (Das et al., 2008). Isabel M. Lima et al., (2015), studied wood chips biochar and chicken litter biochar for heavy metal adsorption and reported higher ash content in chicken litter $(11.6 \%)$ and chicken litter derived biochar (13.5 and $40.1 \%)$ then wood chips raw (3.08\%) and derived biochar (2.6 and $5.6 \%)$ at different pyrolysis temperatures (Lima et al., 2015). Higher ash content is particularly useful for low $\mathrm{pH}$ soils as a liming agent.

Apparently, poultry litter biochar contain lower carbon content then plant material derived biochars, and this is confirmed by Das et al., (2008) and Isabel M. Lima et al., (2015).

Poultry litter biochar have higher electrical conductivity than biochars derived from wood, corn stover, grasses and tree leaves (Mingxin Guo, 2012). Study conducted by J.M. Novak et al., (2009), showed that $\mathrm{pH}$ of poultry litter biochar was higher than the $\mathrm{pH}$ of peanut hulls, pecan shells, switch grass and related it with the presence of $\mathrm{Ca}$ and $\mathrm{Mg}$ in the poultry manure, probably due to the concentration of these nutrients through the 
pyrolytic process (Jeffrey M. Novak et al., 2009).

Poultry litter biochars have higher nutrient contents, and being a recalcitrant material then raw poultry litter, it is safer for land applications. Gaskin et.al. (2008) reported that the amount of Nitrogen $(\mathrm{N})$ conserved after pyrolysis is lower for poultry litter versus other feed stocks, and they concluded that high initial nutrient content of poultry litter biochar ensures the resultant amount is still significantly higher overall (Gaskin, 2008). Similar results were reported by Mingxin Guo et.al. (2012), they found incensement of nutrient content in pyrolytic PL biochar then raw poultry litter except nitrogen $(\mathrm{N})$ and found $\mathrm{N}$ loss higher at higher pyrolytic temperature. Further they suggested that animal manure biochar production should be at lower temperature to conserve the nitrogen (Mingxin Guo, 2012).

\section{Poultry litter biochar: Benefits}

It will reduce the cost to dispose of poultry litter, especially in the areas of highly concentrated poultry operations, where nutrient overload is causing environmental hazards (Phil Covell, 2011).

By the production of biochar from poultry litter the storage of the material can be easy and decaying of the biomass can be prevented and it reduces the liability related to pollution from poultry litter for a relatively longer period. Converting poultry litter into biochar can significantly reduce in coop odour. Poultry litter contain phosphate and nitrogen (ammonium ions), which may cause eutrophication but converting PL into PL biochar reduce the risk.

Poultry litter biochar is recalcitrant material and can therefore resides as a significant proportion of the soil carbon fraction aided by its potential for a prolonged life within the soil (Revell, 2011).
As poultry litter biochar is a rich source of macro and micro nutrients which are necessary for the plant growth, it will reduce the cost and usage of synthetic fertilizers for crop production and is much lighter, which make it easier to transport than the raw litter (Revell et al., 2012).

Use of poultry litter biochar reduces the nutrient runoff if applied directly to soil. Steiner et al., (2010), claimed that when mixed with compost prior to field application poultry litter biochar, can help retain nutrients in the soil which might otherwise be lost (Steiner et al., 2010).

The excess heat generated from PL biochar production process (pyrolysis or gasification) may reduce the heating fuel requirements and it may be used directly onsite in different production and processing facilities (IBI, 2012). It will be an approach for combine heat and power (CHP).

Ro et al., (2010) used a commercial pilotscale pyrolysis reactor system to produce combustible gas and biochar from different manures and found that approximately 50\% of the feedstock energy was retained in biochar and $25 \%$ in produced gases. He further suggested copyrolysis of wet animal wastes with the addition of dried and energy dense feedstock such as waste plastic pellets, to produce valuable biochar and extra power simultaneously (Ro, 2010). Potential for added income from selling biochar to a local market or a distributer.

\section{Uses of poultry litter biochar}

\section{As a soil amendment}

Soil amendment with biochar derived from different agricultural waste is a long time practice. Ogawa et al., (1994), described that early Japanese farmers using unique manure called 'haigoe' prepared by adding human 
waste to rice husk biochar and leaving it for some time before planting crops. The discovery of Terra Preta (in Portuguese meaning -dark earth) soils in the central Amazon Basin implicates that biochar may be an ideal soil amendment for fertility improvement (Neves, 2001). Biochar may retain $\mathrm{NH}_{4}-\mathrm{N}$. Steiner et al., (2008) reported increased recovery of $15 \mathrm{~N}$-labeled $\mathrm{N}$ fertilizer on charcoal-amended soil in comparison to soil without charcoal (Steiner, 2008).

Higher soil enzymatic activity is a positive indicator of higher soil fertility and good quality, changes in enzymatic activity indicates about the changes taking place in the soil environment (Ouyang, 2014). In general, a positive effect of biochar amendment is observed in most studies which focuse on soil biological properties, including enzymatic activity (Mierzwa-Hersztek et al., 2016).

Chan et al., (2008), produced two biochars from poultry litter under different conditions and tested them in a pot trial for assessing the yield of radish (Raphanus sativus var. Long Scarlet). They applied four ratios of biochar, with and without nitrogen application and found detectable increases in dry matter yield of radish in biochars without $\mathrm{N}$ fertilizer even at lower application rate of biochar. The yield increase $(\%)$, compared with the unamended control rose from $42 \%$ at 10 t/ha to $96 \%$ at 50 t/ha of biochar application (Chan, 2008). Similar findings were also reported by many other investigators.

Coomer et al., (2012) studied poultry litter biochar effect on early season cotton growth and indicated that the higher level PL biochar with fertilizer showed significant increases in plant height, dry weight and leaf, area over controls, and reported highest level of biochar $(3,000 \mathrm{~kg}$ biochar/ha) with additional urea fertilizer (50 lb. N/acre) provided the best growth response (Coomer, 2012).
Increased sorption capacity of the soil was reported by Paz-Ferreiro et al., (2012) after amendment with biochar and mineral components into the soil (Paz-Ferreiro et al., 2012).

Ameloot et al., (2013b) showed that the type of biochar alone has a significant effect on soil enzymatic activity, they proved that poultry litter biochar produced at $400^{\circ} \mathrm{C}$ and amended to soil caused a significant increase in the activity of dehydrogenases enzyme, whereas the same biochar obtained at $500^{\circ} \mathrm{C}$ reduced the activity of these enzymes over two times compared to the control (Ameloot, 2013b.).

Mierzwa-Hersztek et al., (2016), observed a positive correlation between the poultry litter biochar dose and activity of the soil enzymes, with an increase of 3\% and 32\% in the activity of dehydrogenase and ureases in the soil amended with a higher dose of PL biochar. They reported a dose of 2.25 or $5 \mathrm{t}$ DM $\mathrm{ha}^{-1}$ of poultry litter biochar to soil, reduced the soil acidity and increased the content of nitrogen and organic carbon when compared to the control (Mierzwa-Hersztek et al., 2016).

Poultry litter biochar have many valuable effects on soil properties, including improvement in the water holding capacity (WHC), cation exchange capacity (CEC), bulk density (BD), and nutrient status and these properties should be considered during formation an appropriate rate of application (Revell et al., 2012).

\section{Use of Poultry litter biochar in poultry farming: A new insight}

Gerlach and Schmidt (2014), pointed out the use of biochar as feed additive and as litter amendment. With a very high water holding capacity biochar can absorb up to 5 times its own weight of water and can adsorbs very 
efficiently both organic molecules such as amino acids, fatty acids, proteins and urea and also mineral compounds such as ammonium, ammonia and nitrate (Gerlach, 2014).

Biochar can locks the moisture and organic and inorganic nitrogen compounds in, if used in litter, which decreases the risk of footpad diseases. High adsorption capacity of biochar makes it possible to reduce the use of lime in the litter, thereby reducing the $\mathrm{pH}$ of the litter and manure, which in turn reduces ammonia emissions (Gerlach, 2014).

If poultry litter is converted to biochar onsite it will be useful for the above mentioned areas and reduce the burden of transportation and environment harm.

\section{As a plant nutritional value additive}

Low temperature poultry litter biochar is rich in plant macro and micro nutrients like $\mathrm{Mg}$, $\mathrm{Ca}, \mathrm{Fe}, \mathrm{K}, \mathrm{P}, \mathrm{N}, \mathrm{S}$, and due to its relatively higher cation exchange capacity biochar is anticipated to retain more nutrients in soil and decrease nutrient leaching (Mingxin Guo, 2012). There are studies which proves soil fertility improvement after addition of biochar.

Study by A. Inal et al., (2015), evaluated the effect of processed poultry manure and poultry litter biochar at different concentrations on soil chemical properties of a calcareous soil and growth of bean (Phaseolus vulgaris) and maize (Zea mays) plants. They reported increase of plant growth and plant nutrients like $\mathrm{N}, \mathrm{P}, \mathrm{Mn}, \mathrm{Zn}, \mathrm{Cu}$ concentrations in soil and also reported the increased concentration of exchangeable cations (K, Ca, Mg) in soil (Inal, 2015). These results revealed that poultry manure biochar can be used effectively for agricultural purpose.
Greenhouse plotting experiments carried out by Mingxin Guo et al., (2012) showed that chemical fertilizer and poultry litter biochar amendment soil plants had stimulated plant growth (Mingxin Guo, 2012).

\section{For environmental management}

From a long time carbonaceous material have been used as sorbents for organic and inorganic contaminants in soil and water (Ahmad et al., 2012). Anthropogenic activities, such as smelting, mining, use of pesticides, fertilizers, sludge, dyes, antibiotics are responsible for the input of heavy metals and organic contaminants into the soil and water at a higher level, biochar has the ability to absorb organic contaminants, immobilized heavy metals and nutrient from soil (Mingxin Guo, 2012). Biochars have a non-carbonized fraction which may interact with soil contaminants and oxygen containing carboxylic, hydroxyl and phenolic surface functional groups in biochar could effectively bind soil contaminants (Ahmad et al., 2014; Uchimiya et al., 2010c).

Cao et al., (2009) investigated the sorption capacities of dairy manures biochar produced at low temperatures $\left(200^{\circ} \mathrm{C}\right.$ and $\left.350^{\circ} \mathrm{C}\right)$ and found that the biochar was six times more effective in removing lead $(\mathrm{Pb})$ from wastewater than a commercial activated carbon (Cao and 2009).

Uchimiya et al., (2011) investigated alkaline soils amended with broiler litter-derived biochars and steam-activated carbons for the retention of $\mathrm{Pb}$ (II), $\mathrm{Cd}$ (II), and $\mathrm{Ni}$ (II). Majority of $\mathrm{Pb}$ (II) was retained, more than half of added Cd (II) and $\mathrm{Ni}$ (II) remained soluble, in soil without biochar and a proportional decrease in soluble Cd (II) and $\mathrm{Ni}$ (II) concentrations was observed with increase in the dose of broiler litter biochar from 5 to $20 \%$, which proves enhanced 
immobilization of heavy metals with the addition of broiler litter biochar in soil (Uchimiya et al., 2010b). Comis (2010) reported that PL biochar binds certain toxic chemicals such as copper, cadmium and zinc from water [(Comis, 2010 (November/December)].

Experiments done by Guo et al., (2010), revealed rapid and significantly higher adsorption affinity of poultry litter-based activated carbon than commercial activated carbons derived from bituminous coal and coconut shell for heavy metals and also reported that releases of nutrients and metal ions from litter-derived carbon did not pose secondary water contamination risks (Guo, 2010).

Isabel M. Lima et al., (2015) used three different activation protocols (acid, base and steam) for pine wood and chicken litter biochars to obtain higher surface area to increase $\mathrm{Cu}$ ion adsorption and reported changes in various chemical properties due to biochar activation, which led to significant changes in surface functionality resulting increased copper ion adsorption (Lima et al., 2015).

Tests done by the USDA Agricultural Research Service (ARS) and Western Kentucky University demonstrated that a combination of PL biochar and poultry litter were effective in reducing ammonia emissions by more than $90 \%$ - highlighting that biochar could be used to reduce ammonia emissions in livestock production facilities (Lovanh, 2010). These results show that the biochars have potential to minimize nutrient leaching in agricultural fields.

$\mathrm{Cu}^{2+} \mathrm{Cd}^{2+}$ and $\mathrm{Zn}^{2+}$ adsorption by broiler litter bio-chars (activated) made from fast pyrolysis was reported 95\%, 83\%, and 90\%, respectively and increase in surface area was also reported due to activation process (Lima et al., 2010).

To promote utilization of poultry litter as a source material for manufacturing low-cost activated carbon (AC), Guo and Song (2011), prepared activated carbon from pelletized broiler litter and used it in wastewater treatment for benzene. Although the sorption capacity of obtained biochar was found lower than that of top-class commercial $\mathrm{AC}$ for benzene, but their findings suggested poultry litter as a cost-effective feedstock for low-cost $\mathrm{AC}$ production which can be used for pretreatment of wastewater contaminated by organic pollutants and heavy metals (Guo, 2011).

Lima et.al. (2005) compared poultry manurebased carbons with two commercial carbons and three traditional precursors, coal, coconut and wood carbons for $\mathrm{Ni}, \mathrm{Zn}, \mathrm{Cd}$ and $\mathrm{Cu}$ adsorption from solutions containing individual ions or the four metal ions present together and reported outperformance for poultry manure based biochar.

The activation strategy, longer activation times and higher water flow rates, are the influencing factors to determine the ability of carbon to absorbe the metal, in the presence of a single metal solution (Lima, 2005).

Granular activated carbon was made from broiler litter and cake, which was further examined for Copper remediation and comparative studies with commercial carbons revealed the broiler cake-based carbon as having the highest copper ion efficiency (Lima \& Marshall, 2005).

\section{Other applications of poultry litter biochar}

As a value-added strategy for recycling the organic waste, poultry litter can be utilized as a precursor material to synthesize activated 
carbon for treating heavy metal-contaminated water (Uchimiya et al., 2010b). Poultry litter biochar can be an attractive solution for storm water treatment as it can bind with toxic metals and having the good water retention potential, this approach can improve water quality and ease the burden on public water treatment systems (IBI, 2012).

Generally, plant based biochars are low in nutrient contents due to their insufficient ash, nitrogen, phosphorous and potassium contents, which is a disadvantages compared to traditional fertilizers for supplying crop nutrients Poultry litter biochar is high in ash content, which may have positive effects on soil agricultural and biochemical properties (Celya, 2015).

Liang et al., (2014), also observed an increment of the drought resistance of both the bacterial and fungal networks on an Acrisol amended with poultry litter biochar (Liang et al., 2014).

Poultry production is growing day by day and so the waste generated. Production of biochar from poultry litter is a promising, practically effective and environmentally sustainable approach to manage the organic waste. Affinity of poultry litter biochar to bind with metals and minerals make it useful for soil and water remediation. In many ways pyrolysed poultry litter is proven to be more effective to use rather poultry litter. Although literature is available for PL and PL biochar still there is scope for future research in the field of energy production, poultry litter and derived biochar induced toxicity in soil, amount of biochar to be used for different kinds of soils for amendments. It is important to understand how biochar made from poultry litter affects soil properties and crop production. Besides it negative effects of poultry litter biochar should not be neglected.

\section{References}

Aditya Parmar, P.K.N., Tripti Agarwal1. 2014. Biochar production from agrofood industry residues: a sustainable approach for soil and environmental management. Current Science, 107 (10).

Ahmad, M., Rajapaksha, A.U., Lim, J.E., Zhang, M., Bolan, N., Mohan, D., Vithanage, M., Lee, S.S., Ok, Y.S. 2014. Biochar as a sorbent for contaminant management in soil and water: a review. Chemosphere, 99, 1933.

Ahmad, M., Usman, A.R.A., Lee, S.S., Kim, S.-C., Joo, J.-H., Yang, J.E., Ok, Y.S. 2012. Eggshell and coral wastes as low cost sorbents for the removal of $\mathrm{Pb} 2+$, $\mathrm{Cd} 2+$ and $\mathrm{Cu} 2+$ from aqueous solutions. Journal of Industrial and Engineering Chemistry, 18 (1), 198204.

Ameloot, N., De Neve, S., Jegajeevagan, K., Yildiz, G., Buchan, D., Funkuin, Y.N., Prins, W., Bouckaert, L., Sleutel, S.,. 2013b. Short-term CO2 and N2O emissions and microbial properties of biochar amended sandy loam soils. Soil Biol. Biochem., 57, 401-410.

Brownsort, P.A. 2009. Biomass pyrolysis processes: performance parameters and their influence on biochar system benefits. A dissertation presented for the degree of Master of Science, University of Edinburgh.

Cao, X., L. Ma, B. Gao, and W. Harris,. 2009. Dairy-Manure Derived Biochar Effectively Sorbs Lead and Atrazine. Environmental Science and Technology, 49 (9), 3285-3291.

Celya, P., G.G., J. Paz-Ferreirob, A. Méndez. 2015. Agronomic properties of biochars from different manure wastes. Journal of Analytical and Applied Pyrolysis.

Comis, D. 2010 (November/December). 
Better Ballfields and Rain Gardens Start Below the Surface. Agricultural Research Magazine, 58 (10).

Crippen, T.L., Sheffield, C.L., Byrd, J.A., Esquivel, J.F., Beier, R.C., Yeater, K. 2016. Poultry litter and the environment: Physiochemical properties of litter and soil during successive flock rotations and after remote site deposition. Sci Total Environ, 553, 65061.

Das, K.C., Garcia-Perez, M., Bibens, B., Melear, N. 2008. Slow pyrolysis of poultry litter and pine woody biomass: impact of chars and bio-oils on microbial growth. J Environ Sci Health A Tox Hazard Subst Environ Eng, 43 (7), 714-24.

Demirbas, A. 2004. Effects of temperature and particle size on bio-char yield from pyrolysis of agricultural residues. Journal of Analytical and Applied Pyrolysis, 72 (2), 243-248.

Dunkley, C.S., Cunningham, Dan L., Harris, Glendon H. 2011. The Value of Poultry Litter in South Georgia. University of Georgia.

Gaskin, J.W., Steiner C., Harris K., Das K. C., and Bibens B. 2008. Effect of low- temperature pyrolysis conditions on biochar for agricultural use. Transactions of the Asabe. Transactions of the Asabe, 51 (6), 2061-2069.

Gerlach H, S.H. 2014. Biochar in poultry farming. The Biochar Journal, Arbaz, Switzerland, www.biocharjournal.org/en/ct/10 Version of 01 th August 2014

Guo M, Q.G., Song W. 2010. Poultry litterbased activated carbon for removing heavy metal ions in water. Waste Management, 2010 (2), 308-15.

Guo M, S.W. 2011. Converting poultry litter to activated carbon: optimal carbonization conditions and product sorption for benzene. Environ Technol.,
33 (15-16), 1789-98.

IBI. 2012. Poultry Litter Biochar - a US Perspective.

Inal, A., Gunes, A., Sahin, O., Taskin, M. B. and Kaya, E. C.. 2015. Impacts of biochar and processed poultry manure, applied to a calcareous soil, on the growth of bean and maize.. Soil Use and Management, 31, 106-113.

Jeffrey M. Novak, I.L., Baoshan, Xing, J.W.G., Christoph Steiner,, K.C. Das, M.A., Djaafar, Rehrah, D.W.W., Warren J., Busscher, H.S. 2009. Characterization of designer biochar produced at different temperatures and their effects on a loamy sand. Annals of Environmental Science, 3

Judy A Libra, K.S.R., Maria-Magdalena Titirici, Claudia Kammann, Christoph Fühner, Axel Funke, Oliver Bens, Nicole D Berge, Jürgen Kern, York Neubauer \& Karl-Heinz Emmerich1. 2011. Hydrothermal carbonization of biomass residuals: a comparative review of the chemistry, processes and applications of wet and dry pyrolysis. Biofules, 2 (1), 89-124.

K. Y. Chan, E., L. Van Zwieten, I. Meszaros, A. Downie, S. Joseph. 2008. Using poultry litter biochars as soil amendments. Australian Journal of Soil Research.

Kithome, M., J.W. Paul, and A.A. Bomke. 1999. Reducing nitrogen losses during simulated composting of poultry manure using adsorbents or chemical amendments. J. Environ. Qual., 28, 194-201.

Kloss, S., Zehetner, F., Dellantonio, A., Hamid, R., Ottner, F., Liedtke, V., Schwanninger, M., Gerzabek, M.H., Soja, G. 2012. Characterization of slow pyrolysis biochars: effects of feedstocks and pyrolysis temperature on biochar properties. J Environ Qual, 41 (4), 9901000. 
Liang, C., Zhu, X., Fu, S., Méndez, A., Gascó, G., Paz-Ferreiro, J. 2014. Biochar alters the resistance and resilience to drought in a tropical soil. Environmental Research Letters, 9 (6), 064013.

Lima, I., Ro, K., Reddy, G., Boykin, D., Klasson, K. 2015. Efficacy of Chicken Litter and Wood Biochars and Their Activated Counterparts in Heavy Metal Clean up from Wastewater. Agriculture, 5 (3), 806-825.

Lima, I.M., Boateng, A.A., Klasson, K.T. 2010. Physicochemical and adsorptive properties of fast-pyrolysis bio-chars and their steam activated counterparts. Journal of Chemical Technology \& Biotechnology, n/a-n/a.

Lima, I.M., Marshall, W.E. 2005. Granular activated carbons from broiler manure: physical, chemical and adsorptive properties. Bioresour Technol, 96 (6), 699-706.

Lima, I.M., Marshall, Wayne E. 2005. Adsorption of selected environmentally important metals by poultry manurebased granular activated carbons. Journal of Chemical Technology \& Biotechnology, 80 (9), 1054-1061.

Lovanh, N.C., Loughrin, J.H., Sistani, K.R.. 2010. Abiotic and Biotic Effect of Poultry Litter Biochar on Ammonia Removal. Conference abstract at USBI, Ames, IA.

Mohamed Amanullah, M., S.S., P. Muthukrishnan. 2010. Prospects and potential of poultry manure. Asian Journal of Plant Sciences, 9 (4).

Mierzwa-Hersztek, M., Gondek, K., Baran, A. 2016. Effect of poultry litter biochar on soil enzymatic activity, ecotoxicity and plant growth. Applied Soil Ecology, 105, 144-150.

Mingxin Guo, Y.S., Zhongqi He. 2012. Poultry litter-based biochar: preparation, characterization and utilization. Applied Research of Animal Manure.

Mohan, D., Sarswat, A., Ok, Y.S., Pittman, C.U., Jr. 2014. Organic and inorganic contaminants removal from water with biochar, a renewable, low cost and sustainable adsorbent--a critical review. Bioresour Technol, 160, 191-202.

Neves, E.G., R.N. Bartone, J. B. Petersen, and M.J. Heckenberger. 2001. The timing of Terra Preta formation in the central Amazon: new data from three sites in the central Amazon. p. 10.

Ouyang, L., Tang, Q., Yu, L., Zhang, R. 2014. Effects of amendment of different biochars on soil enzyme activities related to carbon mineralisation. Soil Res, 52 (7), 706-716.

Paz-Ferreiro, J., Gasco, G., Gutierrez, B., Mendez, A. 2012. Soil biochemical activities and the geometric mean of enzyme activities after application of sewage sludge and sewage sludge biochar to soil. Biology and Fertility of Soils, 48 (5), 7.

Phil Covell, G.G., Suzanne Hunt, Lopa Brunjes, Fai Ng, Dan Nees. 2011. Advancing Biochar in the Chesapeake: A Strategy to Reduce Pollution from Poultry Litter. Forest Trends/Katoomba Incubator, Carbon War Room, Forest Trends/Chesapeake Fund. Available at: http://www.forest - trends.org/publicatio n_details.php?publicationID=2891.

Prabhu, M.J. 2009. Benefits from poultry manure - no chicken feed.

Rajesh Mehta, R.G.N. The poultry industry in India. Poultry in the 21st Century,

Revell, K.T. 2011. The Effect of Fast Pyrolysis Biochar Made From Poultry Litter on Soil Properties and plant growth. faculty of the Virginia Polytechnic Institute and State University (Thesis).

Revell, K.T., Maguire, R.O., Agblevor, F.A. 2012. Influence of Poultry Litter 
Biochar on Soil Properties and Plant Growth. Soil Science, 177 (6), 402-408.

Ro, K.S., Cantrell, K.B., Hunt, P.G. 2010. High-temperature pyrolysis of blended animal manures for producing renewable energy and value-added biochar. Industrial \& Engineering Chemistry Research, 49, 10125-10131.

Song, W., Guo, M. 2012. Quality variations of poultry litter biochar generated at different pyrolysis temperatures. Journal of Analytical and Applied Pyrolysis, 94, 138-145.

Steiner, C., B. Glaser, W.G. Teixeira, J. Lehmann, W.E.H. Blum, and W. Zech. 2008. Nitrogen retention and plant uptake on a highly weathered central Amazonian Ferralsol amended with compost and charcoal. J. Plant Nutr. Soil Sci., 171, 893-899.

Steiner, C., Das, K.C., Melear, N., Lakly, D. 2010. Reducing Nitrogen Loss during Poultry Litter Composting Using Biochar. Journal of Environment Quality, 39 (4), 1236.

Sun, Y., Gao, B., Yao, Y., Fang, J., Zhang, M., Zhou, Y., Chen, H., Yang, L. 2014. Effects of feedstock type, production method, and pyrolysis temperature on biochar and hydrochar properties.
Chemical Engineering Journal, 240, 574-578.

T.D. Coomer, D.M.O., D.E. Longer, and D.A. Loka. 2012. Effect of Poultry Litter Biochar on Early-Season Cotton Growth. Summaries of Arkansas Cotton Research.

Uchimiya, M., Lima, I.M., Klasson, K.T., Wartelle, L.H. 2010a. Contaminant immobilization and nutrient release by biochar soil amendment: roles of natural organic matter. Chemosphere, 80 (8), 935-40.

Uchimiya, M., Lima, I.M., Thomas Klasson, K., Chang, S., Wartelle, L.H., Rodgers, J.E. 2010b. Immobilization of heavy metal ions (CuII, CdII, NiII, and PbII) by broiler litter-derived biochars in water and soil. J Agric Food Chem, 58 (9), 5538-44.

Uchimiya, M., Wartelle, L.H., Lima, I.M., Klasson, K.T. 2010c. Sorption of deisopropylatrazine on broiler litter biochars. J Agric Food Chem, 58 (23), $12350-6$.

Williams, C.M., Barker, J.C., Sims, J.T. 1999. Management and utilization of poultry wastes. Rev Environ Contam Toxicol, 162, 105-57.

\section{How to cite this article:}

Amita Shakya and Tripti Agarwal. 2017. Poultry Litter Biochar: An Approach towards Poultry Litter Management - A Review. Int.J.Curr.Microbiol.App.Sci. 6 (10): 2657-2668. doi: https://doi.org/10.20546/ijcmas.2017.610.314 